\title{
ABBREVIATIONS AND A NOTE ON SPELLING
}

\author{
Abbreviations
}

LMS London Missionary Society

RGS Royal Geographical Society

UMCA Universities' Mission to Central Africa

Note on spelling

Today, the river that Livingstone hoped would open the African continent to commerce and Christianity is spelt 'Zambezi'. Throughout this book, however, I have followed Livingstone's spelling, 'Zambesi', for the sake of consistency. 
Justin D. Livingstone - 9781847799135 Downloaded from manchesterhive.com at $04 / 26 / 2023$ 02:16:19PM via free access 